\title{
Radiation Intensity and Quality from Sole-source Light-emitting Diodes Affect Seedling Quality and Subsequent Flowering of Long-day Bedding Plant Species
}

\author{
Joshua K. Craver ${ }^{1,2}$ \\ Department of Horticulture and Landscape Architecture, Purdue University, \\ West Lafayette, IN 47907 \\ Jennifer K. Boldt \\ USDA-ARS, Greenhouse Production Research Group, Toledo, OH 43606
}

\author{
Roberto G. Lopez ${ }^{3,4}$ \\ Department of Horticulture, Michigan State University, East Lansing, MI 48824
}

Additional index words. controlled environment agriculture, daily light integral, far-red radiation, plugs, indoor vertical production

\begin{abstract}
Previous research has shown high-quality annual bedding plant seedlings can be produced in controlled environments using light-emitting diode (LED) sole-source lighting (SSL). However, when only red and blue radiation are used, a delay in time to flower may be present when seedlings of some long-day species are subsequently finished in a greenhouse. Thus, our objective was to evaluate the effects of various radiation qualities and intensities under SSL on the morphology, nutrient uptake, and subsequent flowering of annual bedding plant seedlings with a long-day photoperiodic response. Coreopsis (Coreopsis grandiflora 'Sunfire'), pansy (Viola $\times$ wittrockiana 'Matrix Yellow'), and petunia (Petunia $\times$ hybrida 'Purple Wave') seedlings were grown at radiation intensities of 105,210 , or $315 \mu \mathrm{mol} \cdot \mathrm{m}^{-2} \cdot \mathrm{s}^{-1}$, achieved from $L E D$ arrays with radiation ratios (\%) of red:blue 87:13 $\left(\mathbf{R}_{87}: B_{13}\right)$, red:far-red:blue 84:7:9 $\left(\mathbf{R}_{84}: F: \mathbf{R}_{7}\right)$, or red: green:blue 74:18:8 $\left(R_{74}: G_{18}: B_{8}\right)$. Four-week-old seedlings were subsequently transplanted and grown in a common greenhouse environment. Stem caliper, root dry mass, and shoot dry mass of seedlings generally increased for all three species as the radiation intensity increased from 105 to $315 \mu \mathrm{mol} \cdot \mathrm{m}^{-2} \cdot \mathrm{s}^{-1}$, regardless of radiation quality. Similarly, stem length of all three species was generally shorter as the radiation intensity increased. Macro- and micronutrient concentrations were also generally lower as the radiation intensity increased for all three species. Pansy seedlings grown under $R_{84}: F R_{7}: B_{9}$ flowered an average of 7 and 5 days earlier than those under $R_{87}: B_{13}$ and $R_{74}: G_{18}: B_{8}$, respectively. These results provide information regarding the specific radiation parameters from commercially available LEDs necessary to produce high-quality seedlings under SSL, with radiation intensity appearing to be the dominant factor in determining seedling quality. Furthermore, the addition of far-red radiation can reduce time to flower after transplant and allow for a faster greenhouse turnover of some species with a long-day photoperiodic response.
\end{abstract}

The production of young plants from seed (plugs) for the annual bedding plant market commonly occurs during winter and early spring (Styer, 2003). However, in northern

Received for publication 2 May 2018. Accepted for publication 27 July 2018.

We gratefully acknowledge Maria Del Rosario Del Rio for growth chamber and laboratory assistance; the USDA-NIFA SCRI grant No. 2010-51181-21369 for funding; and Philips Lighting and Hort Americas for LED lighting. The use of trade names in this publication does not imply endorsement by Purdue University, USDA-ARS, or Michigan State University of products named nor criticism of similar ones not mentioned.

${ }^{1}$ Former Graduate Student.

${ }^{2}$ Current address: Department of Horticulture and Landscape Architecture, Colorado State University, Fort Collins, CO 80523.

${ }^{3}$ Assistant Professor and Extension Specialist.

${ }^{4}$ Corresponding author. E-mail: rglopez@msu.edu. latitudes, the natural photosynthetic daily light integral (DLI) is not sufficient to produce high-quality young plants in the greenhouse (Lopez and Runkle, 2008; Pramuk and Runkle, 2005). Previous research has shown that a minimum DLI of 10 to $12 \mathrm{~mol} \cdot \mathrm{m}^{-2} \cdot \mathrm{d}^{-1}$ is recommended to produce high-quality ornamental young plants (Pramuk and Runkle, 2005; Randall and Lopez, 2014). Thus, to efficiently produce seedlings in northern latitudes, where the DLI in the greenhouse can be as low as 1 to $5 \mathrm{~mol} \cdot \mathrm{m}^{-2} \cdot \mathrm{d}^{-1}$ during winter and early spring, supplemental lighting is recommended (Pramuk and Runkle, 2005). Currently, high-pressure sodium (HPS) lamps are the industry standard for providing supplemental lighting, with a photosynthetic photon flux density $(P P F D)$ of 70 to $90 \mu \mathrm{mol} \cdot \mathrm{m}^{-2} \cdot \mathrm{s}^{-1}$ commonly targeted (Lopez et al., 2017). One alternative to traditional greenhouse production is multilayer or vertical production indoors in repurposed shipping containers, warehouses, or chambers under sole-source lighting (SSL) provided by light-emitting diodes (LEDs). While SSL applications may not be suitable for all crops, young plant production is one area that may benefit substantially from this technology as growers strive to produce a uniform, high-quality crop during months of the year where greenhouse environmental conditions are both unpredictable and unfavorable. Additionally, young plant production may provide one of the most costeffective applications for SSL due to the small size and high value of plugs and relatively short production cycle (Park and Runkle, 2017).

Previous research has shown that LED SSL in controlled environments is a promising lighting method for the production of annual bedding plant seedlings (Randall and Lopez, 2015; Wollaeger and Runkle, 2014). Specifically, Randall and Lopez (2015) evaluated seedlings of vinca (Catharanthus roseus 'Titan Red Dark'), impatiens (Impatiens walleriana 'Super Elfin XP Blue Pearl'), geranium (Pelargonium $\times$ hortorum 'Bullseye Red'), petunia (Petunia $\times$ hybrida 'Dreams Midnight'), and French marigold (Tagetes patula 'Durango Yellow') under SSL using LEDs providing a red:blue radiation ratio $(\%)$ of either $87: 13$ or $70: 30$. Generally, they found that seedlings produced under controlled-environment SSL were more compact, darker in foliage color (higher relative chlorophyll content), and had a higher root mass than those produced under greenhouse supplemental lighting or ambient lighting conditions.

Increases in radiation intensity and DLI have been reported to increase seedling quality and decrease subsequent time to flower (TTF) for many bedding plant species (Oh et al., 2010; Pramuk and Runkle, 2005). Seedlings produced under lower DLIs generally show decreased growth rates and possess more water in the plant tissues, ultimately leading to seedlings that growers would refer to as being less "toned" (Faust et al., 2005). For example, Pramuk and Runkle (2005) found that as the DLI increased from 4.1 to $14.2 \mathrm{~mol} \cdot \mathrm{m}^{-2} \cdot \mathrm{d}^{-1}$ during seedling production, the average shoot dry mass (SDM) per internode increased linearly for celosia (Celosia argentea var. plumosa 'Gloria Mix'), impatiens 'Accent Red', French marigold 'Bonanza Yellow', and pansy (Viola $\times$ wittrockiana 'Crystal Bowl Yellow').

One of the benefits LEDs provide is the ability to select specific wavelengths of radiation to elicit desired morphological or physiological plant responses. Red wavelengths are most commonly associated with their role in photosynthesis and dry mass accumulation based on their action at the absorption peaks of chlorophylls (Massa et al., 2008). Compared with red radiation, blue wavelengths are believed to be less photosynthetically efficient due to their absorption by pigments other than chlorophyll 
and resulting low quantum efficiency (Barnes et al., 1993; Cope et al., 2014; Franklin, 2008; Massa et al., 2008). Another reason for the loss in photosynthetic activity may be due to smaller leaf area, which has been observed under high percentages of blue radiation and ultimately leads to decreased radiation interception (Cope et al., 2014). However, this inhibition response to blue wavelengths may be desirable for many crops as a means of controlling excessive growth (Cope et al., 2014; Cosgrove, 1981; Kigel and Cosgrove, 1991; Runkle and Heins, 2001). Thus, LEDs can be manufactured with a variety of plant responses in mind, such as the control of stem elongation or matching the absorbance peaks of photoreceptors involved in photosynthesis (Mitchell et al., 2012).

Additionally, Stutte (2009) found that the phytochrome photostationary state, the relative proportion of the active form to total phytochrome, could be manipulated using LEDs to either initiate earlier flowering or promote continued growth in the vegetative state for photoperiod-sensitive species. Farred radiation has a significant effect in the processes of stem elongation and flowering (Downs and Thomas, 1982). For example, a deficiency in far-red radiation has often been found to delay flower initiation or development in species with a long-day photoperiodic response such as campanula (Campanula carpatica 'Blue Clips'), coreopsis (Coreopsis ×grandiflora 'Early Sunrise'), and pansy 'Crystal Bowl Yellow' (Runkle and Heins, 2001). Thus, reductions in radiation intensity as well as the lack of critical wavelengths in environments using SSL may lead to delays in flowering and a reduction in seedling quality for some species.

While limited research has been conducted on the effects of radiation quality for young-plant production in controlled environments under SSL, to our knowledge, no research to date has evaluated how the manipulation of radiation quality across various radiation intensities might further impact bedding plant seedling quality and TTF under SSL conditions. Additionally, by furthering our understanding regarding the impacts of LED SSL on nutrient uptake, a more thorough outlook on how to optimize production within these environments may be provided. We also postulated that the inclusion of far-red radiation during seedling propagation would initiate earlier flowering at finishing for species with a long-day photoperiodic response. Thus, the objective of the study was to evaluate the effects of various radiation qualities and intensities in a SSL environment on the morphology, nutrient uptake, and subsequent flowering of annual bedding plant seedlings.

\section{Materials and Methods}

Plant material and germination environment. Based on their significance to the greenhouse industry and long-day photoperiodic flowering response (Currey et al.,
2011; Runkle and Heins, 2001), seeds of coreopsis 'Sunfire', pansy 'Matrix Yellow', and petunia 'Purple Wave' were sown between 8 Oct. 2014 and 8 Jan. 2015 in 288-cell trays (6-mL individual cell volume) using a commercial soilless medium comprised of (by vol.) $65 \%$ peat, $20 \%$ perlite, and $15 \%$ vermiculite (Fafard Super Fine Germinating Mix; Sun Gro Horticulture, Agawam, MA) and germinated under a $16 \mathrm{~h}$ photoperiod (0600 to $2200 \mathrm{HR}$ ) in a glass-glazed greenhouse at Purdue University, West Lafayette, IN (lat. $40^{\circ} \mathrm{N}$ ). An environmental control system (Maximizer Precision 10; Priva Computers Inc., Vineland Station, Ontario, Canada) was used to adjust and measure the greenhouse air temperature. Supplemental lighting was provided by $1000-\mathrm{W}$ HPS lamps, and solar PPFD (400-700 nm) was measured by quantum sensors (SQ-110; Apogee Instruments, Inc., Logan, UT) every $15 \mathrm{~s}$ and the average was logged every $15 \mathrm{~min}$ by a data logger (Model CR1000; Campbell Scientific, Inc., Logan, UT). The mean \pm SD DLI and average daily air temperature (ADT) from sowing to hypocotyl emergence were $7.5 \pm 1.7 \mathrm{~mol} \cdot \mathrm{m}^{-2} \cdot \mathrm{d}^{-1}$ and $22.7 \pm 0.3{ }^{\circ} \mathrm{C}$, respectively. Trays were regularly misted using clear water to maintain high humidity and soil moisture until germination occurred.

Growth chamber environment. Upon uniform hypocotyl emergence within each species, plug trays were placed under SSL treatments with a $16 \mathrm{~h}$ photoperiod $(0600$ to $2200 \mathrm{HR}$ ) in a walk-in growth chamber (C5 Control System; Environmental Growth Chambers, Chagrin Falls, OH). The air temperature, relative humidity, and $\mathrm{CO}_{2}$ set points were $21{ }^{\circ} \mathrm{C}, 70 / 80 \%$ day/night $(\mathrm{D} / \mathrm{N}$; $16 \mathrm{~h} / 8 \mathrm{~h}$ ), and $500 \mu \mathrm{mol} \cdot \mathrm{mol}^{-1}$, respectively. A data logger (DL1 Datalogger; Environmental Growth Chambers) was used to record average air temperature, $\mathrm{D} / \mathrm{N}$ relative humidity, and $\mathrm{CO}_{2}$ concentration every $15 \mathrm{~min}$, with a mean $\pm \mathrm{SD}$ of $21.0 \pm 0.1{ }^{\circ} \mathrm{C}, 69.8 \pm 0.5 \%$ $\mathrm{D} / 79.5 \pm 0.5 \% \mathrm{~N}$, and $499.6 \pm 33.1 \mu \mathrm{mol} \cdot \mathrm{mol}^{-1}$, respectively, across three experimental replications. Seedlings were irrigated daily with water-soluble fertilizer (Jack's LX 16N0.94P-12.3K Plug Formula for High Alkalinity Water; J.R. Peters, Inc., Allentown, PA) providing (in $\mathrm{mg} \cdot \mathrm{L}^{-1}$ ): 100 nitrogen $(\mathrm{N}), 10$ phosphorus $(\mathrm{P}), 78$ potassium $(\mathrm{K}), 18$ calcium $(\mathrm{Ca})$, 9.4 magnesium $(\mathrm{Mg}), 0.10$ boron $(\mathrm{B}), 0.05$ copper $(\mathrm{Cu}), 0.50$ iron $(\mathrm{Fe}), 0.25$ manganese $(\mathrm{Mn}), 0.05$ molybdenum (Mo), and 0.25 zinc ( $\mathrm{Zn}$ ).

Sole-source lighting treatments. A multilayer (three layers) production system was used in the growth chamber for the establishment of SSL treatments. Commerciallyavailable LED arrays providing radiation ratios of red:blue $87: 13\left(\mathrm{R}_{87}: \mathrm{B}_{13}\right)$, red:farred:blue 84:7:9 $\left(\mathrm{R}_{84}: \mathrm{FR}_{7}: \mathrm{B}_{9}\right)$, or red:green: blue 74:18:8 $\left(\mathrm{R}_{74}: \mathrm{G}_{18}: \mathrm{B}_{8}\right)$ (Philips GreenPower LED production modules; Koninklijke Philips Electronics, N.V., Netherlands) were mounted to one of nine stainless steel shelves (123 cm long and $61 \mathrm{~cm}$ wide). Nonreflective blackout cloth was used to prevent radiation pollution between treatments. Radiation intensity treatments were established by mounting
2,4 , or 6 modules, spaced $20.3,12.2$, or $8.6 \mathrm{~cm}$ apart, $\approx 38 \mathrm{~cm}$ above the crop canopy to achieve an average $P P F D$ of 105,210 , or 315 $\mu \mathrm{mol} \cdot \mathrm{m}^{-2} \cdot \mathrm{s}^{-1}$, respectively. A $16 \mathrm{~h}(0600$ to $2200 \mathrm{HR}$ ) photoperiod provided plants with a DLI of $6.1,12.1$, or $18.1 \mathrm{~mol} \cdot \mathrm{m}^{-2} \cdot \mathrm{d}^{-1}$, representing targets below, equal to, or above the recommended minimum target DLI of $10-12 \mathrm{~mol} \cdot \mathrm{m}^{-2} \cdot \mathrm{d}^{-1}$, respectively (Pramuk and Runkle, 2005; Randall and Lopez, 2014). Radiation quality and $P P F D$ were measured at the beginning and confirmed at the end of each experimental replication by taking nine individual spectral scans per treatment using a spectroradiometer (PS-100; StellarNet, Inc., Tampa, FL). Average PPFD and spectral qualities for each treatment are reported in Table 1 and Fig. 1, respectively. Trays were rotated within each treatment daily to reduce any positional effects on radiation distribution.

Seedling data collection. After $28 \mathrm{~d}$ under the SSL treatments, five experimental units (individual seedlings) from each treatment were randomly selected for measurements and analysis. Roots and shoots of the seedlings were washed, and nondestructive measurements were taken for stem length $(\mathrm{cm}$; measured from the base of the hypocotyl to the shoot apical meristem) and stem caliper [mm; measured above the lowest leaf with a digital caliper (digiMax; Wiha, Schonach, Germany)]. Leaf area $\left(\mathrm{cm}^{2}\right)$ was recorded using a leaf area meter (LI-3100; LI-COR Inc., Lincoln, NE) by removing the seedling leaves at the axil. Roots and shoots (leaves and stems) were then separated and placed in a drying oven at $70{ }^{\circ} \mathrm{C}$ for at least $4 \mathrm{~d}$ for the collection of root dry mass (RDM) and SDM. Additionally, stem length and caliper were used to calculate the sturdiness quotient (SQ; stem caliper/stem length) of each seedling. The quality index $\{\mathrm{QI}$; [total dry mass $x$ (shoot:root ratio + sturdiness quotient)] $\}$ was then calculated according to Currey et al. (2013).

Nutrient analysis. After $28 \mathrm{~d}$, shoots of eight seedlings within each treatment were randomly collected, triple rinsed with deionized water, and placed in a drying oven at $70{ }^{\circ} \mathrm{C}$ for at least $4 \mathrm{~d}$. Due to the limited dry mass obtained from a single seedling, eight seedlings provided a single sample for nutrient analysis, with five samples analyzed for each species within each treatment. Foliar N was determined using a CHN analyzer (PerkinElmer Series II CHNS/O Analyzer; PerkinElmer Instruments, Shelton, CT). For all other elements, plant tissue from each sample was digested in a microwave (MARS6; CEM Corp., Matthews, NC) and nutrient concentration was determined using inductively coupled plasma optical emission spectroscopy (ICP-OES; Thermo iCAP 6300; Thermo Electron Corp., Waltham, MA) as described by Frantz (2013).

Finishing environment. After $28 \mathrm{~d}$, five randomly selected seedlings from each treatment were transplanted into $11.4 \mathrm{~cm}(600$ $\mathrm{mL}$ ) containers (Dillen Products, Middlefield, $\mathrm{OH}$ ) filled with a commercial soilless medium comprised of (by vol.) $75 \%$ peat, 
Table 1. Average photosynthetic photon flux density (PPFD) from 400 to $700 \mathrm{~nm} \pm$ sD delivered from solesource light-emitting diodes (LEDs) with radiation ratios (\%) of red:blue 87:13 $\left(\mathrm{R}_{87}: \mathrm{B}_{13}\right)$, red:far-red: blue 84:7:9 $\left(\mathrm{R}_{84}: \mathrm{FR}_{7}: \mathrm{B}_{9}\right)$, or red:green:blue 74:18:8 $\left(\mathrm{R}_{74}: \mathrm{G}_{18}: \mathrm{B}_{8}\right)$ to achieve target radiation intensities of 105,210 , and $315 \mu \mathrm{mol} \cdot \mathrm{m}^{-2} \cdot \mathrm{s}^{-1}$. The average daily light integrals (DLIs), measured from 400 to $700 \mathrm{~nm}$, under a $16 \mathrm{~h}$ photoperiod ( 0600 to $2200 \mathrm{HR}$ ) are also reported. Mean values reported are the average of nine spectral scans across the three experimental replications.

\begin{tabular}{llcr}
\hline $\begin{array}{l}\text { Radiation intensity } \\
\text { treatment }\left(\mu \mathrm{mol} \cdot \mathrm{m}^{-2} \cdot \mathrm{s}^{-1}\right)\end{array}$ & $\begin{array}{c}\text { Radiation quality } \\
\text { treatment }(\%)\end{array}$ & $\begin{array}{c}\text { Avg PPFD } \\
\left(\mu \mathrm{mol} \cdot \mathrm{m}^{-2} \cdot \mathrm{s}^{-1}\right)\end{array}$ & Avg DLI $\left(\mathrm{mol} \cdot \mathrm{m}^{-2} \cdot \mathrm{d}^{-1}\right)$ \\
\hline 105 & $\mathrm{R}_{87}: \mathrm{B}_{13}$ & $102.9 \pm 19.3$ & $5.9 \pm 1.1$ \\
& $\mathrm{R}_{84}: \mathrm{FR}_{7}: \mathrm{B}_{9}$ & $103.2 \pm 18.0$ & $5.9 \pm 1.0$ \\
& $\mathrm{R}_{74}: \mathrm{G}_{18}: \mathrm{B}_{8}$ & $103.2 \pm 18.1$ & $5.9 \pm 1.0$ \\
& & & \\
& $\mathrm{R}_{87}: \mathrm{B}_{13}$ & $205.0 \pm 32.7$ & $11.8 \pm 1.9$ \\
& $\mathrm{R}_{84}: \mathrm{FR}_{7}: \mathrm{B}_{9}$ & $208.1 \pm 34.0$ & $12.0 \pm 2.0$ \\
& $\mathrm{R}_{74}: \mathrm{G}_{18}: \mathrm{B}_{8}$ & $206.7 \pm 28.6$ & $11.9 \pm 1.6$ \\
& & & \\
& & $311.9 \pm 52.7$ & $18.0 \pm 3.0$ \\
& $\mathrm{R}_{87}: \mathrm{B}_{13}$ & $310.2 \pm 48.3$ & $17.9 \pm 2.8$ \\
& $\mathrm{R}_{84}: \mathrm{FR}_{7}: \mathrm{B}_{9}$ & $311.0 \pm 52.0$ & $17.9 \pm 3.0$ \\
\hline & $\mathrm{R}_{74}: \mathrm{G}_{18}: \mathrm{B}_{8}$ & & \\
\hline
\end{tabular}

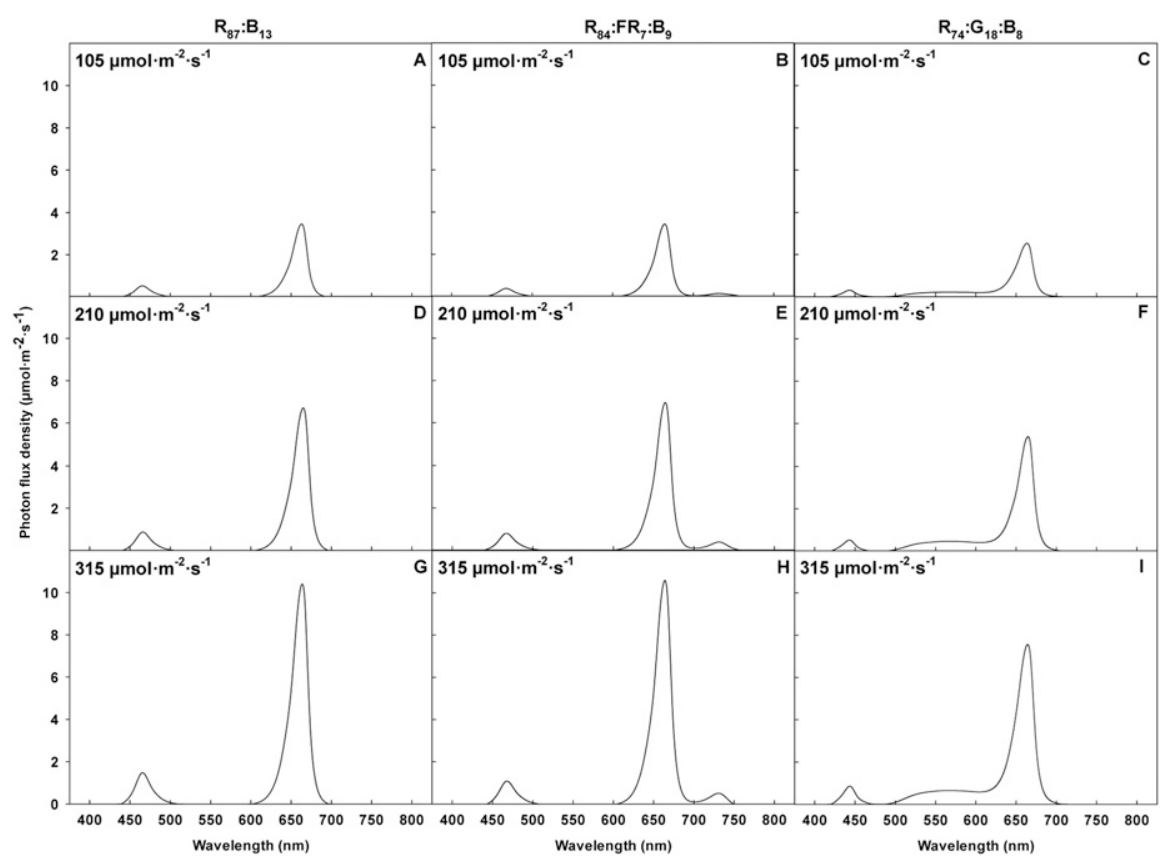

Fig. 1. Spectral quality delivered from sole-source light-emitting diode (LED) arrays with radiation qualities (\%) of red:blue 87:13 $\left(\mathrm{R}_{87}: \mathrm{B}_{13}\right)$, red:far-red:blue 84:7:9 $\left(\mathrm{R}_{84}: \mathrm{FR}_{7}: \mathrm{B}_{9}\right)$, or red:green:blue $74: 18: 8\left(\mathrm{R}_{74}: \mathrm{G}_{18}: \mathrm{B}_{8}\right)$ at a photosynthetic photon flux density from 400 to $700 \mathrm{~nm}$ of 105,210 , or 315 $\mu \mathrm{mol} \cdot \mathrm{m}^{-2} \cdot \mathrm{s}^{-1}$ at canopy level.

$20 \%$ perlite, and $5 \%$ vermiculite (Fafard 2; Sun Gro Horticulture) on 23 Dec. 2014 (Replication 1) and 11 Feb. 2015 (Replication 2). Plants were placed in a common finishing environment with an air temperature set point of $20{ }^{\circ} \mathrm{C}$. An environmental control system (Maximizer Precision 10; Priva Computers Inc.) managed exhaust fan and evaporative-pad cooling, radiant hot water heating, and retractable shade curtains for the greenhouse. Solar $P P F D$ was measured by quantum sensors (SQ-110; Apogee Instruments, Inc.) every $15 \mathrm{~s}$ and the average was logged every $15 \mathrm{~min}$ by a data logger (Model CR1000; Campbell Scientific, Inc.). Supplemental lighting was provided by 1000 W HPS lamps to assist in achieving a minimum DLI of $12 \mathrm{~mol} \cdot \mathrm{m}^{-2} \cdot \mathrm{d}^{-1}$. Average daily temperature and DLI for the two experimental replications beginning on 23 Dec. 2014 and 11 (three levels) as factors and species evaluated separately. The experiment was repeated three times over time for the seedling data collection and twice over time for the finishing data collection. For each replication of the study, one 288-cell tray per species was subjected to each treatment, with individual seedlings within a tray serving as experimental units. The effects of radiation intensity and radiation quality were compared by ANOVA using SAS (SAS version 9.3; SAS Institute, Cary, NC) PROC MIXED and Tukey's honest significant difference test at $P \leq 0.05$. With the majority of variables displaying no significant interaction between radiation intensity and quality (Table 2), main effect means were reported (Tables 3 and 4). Additionally, the factors of radiation intensity and quality were evaluated separately. The effect of radiation intensity was compared within radiation qualities, while the effect of radiation quality was compared within radiation intensities for each species (data not shown).

\section{Results}

Stem length and caliper. Stem length was $9 \%, 16 \%$, and $21 \%$ shorter as radiation intensity increased from 105 to $315 \mu \mathrm{mol} \cdot \mathrm{m}^{-2} \cdot \mathrm{s}^{-1}$ for coreopsis, pansy, and petunia, respectively (Table 3 ). However, differences in stem length between the radiation intensities of 210 and $315 \mu \mathrm{mol} \cdot \mathrm{m}^{-2} \cdot \mathrm{s}^{-1}$ were only present for petunia. Specifically, stem length of petunia was $6 \%$ shorter at a radiation intensity of $315 \mathrm{compared}$ with $210 \mu \mathrm{mol} \cdot \mathrm{m}^{-2} \cdot \mathrm{s}^{-1}$ (Table 3). Stem caliper increased 14\%, 14\%, and $10 \%$ for coreopsis, pansy, and petunia, respectively, at a radiation intensity of 315 compared with $105 \mu \mathrm{mol} \cdot \mathrm{m}^{-2} \cdot \mathrm{s}^{-1}$ (Table 3 ). Additionally, stem caliper of coreopsis increased $6 \%$ at a radiation intensity of 315 compared with $210 \mu \mathrm{mol} \cdot \mathrm{m}^{-2} \cdot \mathrm{s}^{-1}$ (Table 3 ). However, differences in stem caliper between the radiation intensities of 210 and $315 \mu \mathrm{mol} \cdot \mathrm{m}^{-2} \cdot \mathrm{s}^{-1}$ were not observed for pansy and petunia (Table 3 ).

Regarding radiation quality, stem length of pansy was $7 \%$ and $13 \%$ shorter under $R_{87}$ : $\mathrm{B}_{13}$ and $\mathrm{R}_{74}: \mathrm{G}_{18}: \mathrm{B}_{8}$, respectively, compared with $\mathrm{R}_{84}: \mathrm{FR}_{7}: \mathrm{B}_{9}$ (Table 4 ). Likewise, stem length of petunia was $15 \%$ shorter under $R_{87}$ : $\mathrm{B}_{13}$ compared with $\mathrm{R}_{84}: \mathrm{FR}_{7}: \mathrm{B}_{9}$. Stem caliper of coreopsis increased $12 \%$ and $9 \%$ under $R_{84}$ : $\mathrm{FR}_{7}: \mathrm{B}_{9}$ compared with $\mathrm{R}_{87}: \mathrm{B}_{13}$ and $\mathrm{R}_{74}: \mathrm{G}_{18}$ : $\mathrm{B}_{8}$, respectively (Table 4). Additionally, stem caliper of petunia increased $13 \%$ and $11 \%$ under $\mathrm{R}_{84}: \mathrm{FR}_{7}: \mathrm{B}_{9}$ compared with $\mathrm{R}_{87}: \mathrm{B}_{13}$ and $\mathrm{R}_{74}: \mathrm{G}_{18}: \mathrm{B}_{8}$, respectively.

Leaf area. As radiation intensity increased from 105 to $315 \mu \mathrm{mol} \cdot \mathrm{m}^{-2} \cdot \mathrm{s}^{-1}$, leaf area of petunia was $23 \%$ smaller (Table 3 ). Conversely, as radiation intensity increased from 105 to 315 $\mu \mathrm{mol} \cdot \mathrm{m}^{-2} \cdot \mathrm{s}^{-1}$, leaf area of pansy was $16 \%$ larger. Regarding radiation quality, the largest leaf area was observed under $\mathrm{R}_{84}: \mathrm{FR}_{7}: \mathrm{B}_{9}$ for all three species (Table 4). Leaf area of pansy was $18 \%$ larger under $\mathrm{R}_{84}: \mathrm{FR}_{7}: \mathrm{B}_{9}$ compared with $\mathrm{R}_{87}: \mathrm{B}_{13}$, while leaf area of coreopsis and petunia was $29 \%$ and $15 \%$ larger and $27 \%$ and $14 \%$ larger under 
Table 2. Analysis of variance (ANOVA) for the effects of radiation quality (RQ), radiation intensity (RI), or RQ $\times$ RI from sole-source light-emitting diodes (LEDs) on propagation ( $28 \mathrm{~d}$ after germination) and finishing (transplanted $28 \mathrm{~d}$ after germination) for coreopsis (Coreopsis grandiflora 'Sunfire'), pansy (Viola $\times$ wittrockiana 'Matrix Yellow'), and petunia (Petunia $\times$ hybrida 'Purple Wave').

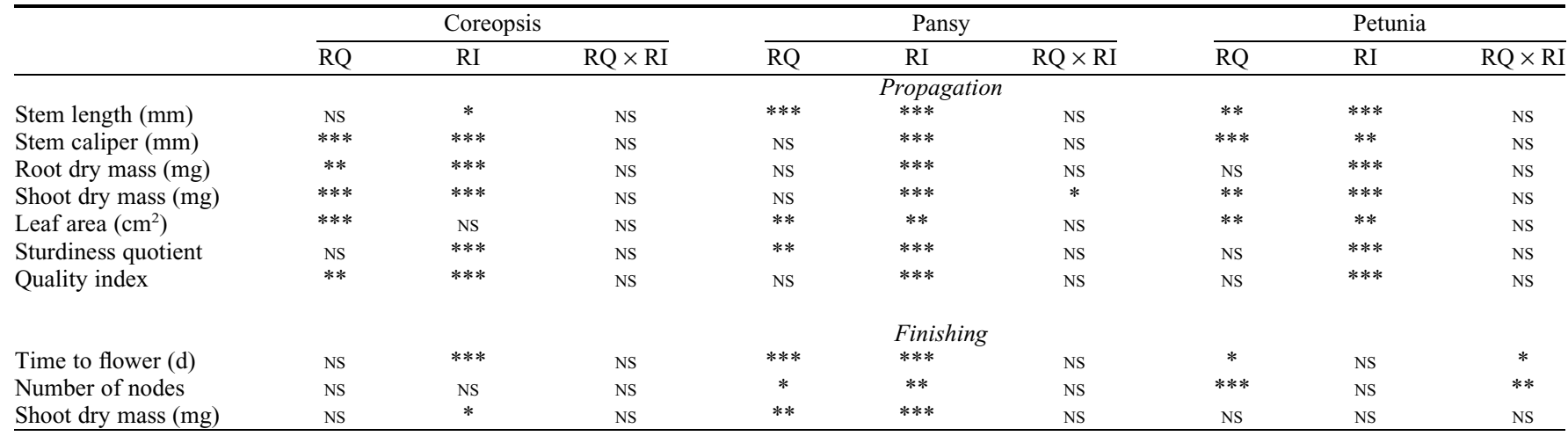

NS, ***,***Nonsignificant or significant at $P \leq 0.05,0.01$, or 0.001 , respectively.

Table 3. Propagation ( $28 \mathrm{~d}$ after germination) and finishing (transplanted $28 \mathrm{~d}$ after germination) data for the main effect of radiation intensity including stem length, stem caliper, leaf area, root (RDM) and shoot dry mass (SDM), sturdiness quotient, quality index, time to flower, number of nodes below the first open flower, and SDM at flowering for coreopsis (Coreopsis grandiflora 'Sunfire'), pansy (Viola $\times$ wittrockiana 'Matrix Yellow'), and petunia (Petunia $\times$ hybrida 'Purple Wave') seedlings grown under radiation intensities of 105,210 , or $315 \mu \mathrm{mol} \cdot \mathrm{m}^{-2} \cdot \mathrm{s}^{-1}$ delivered from sole-source light-emitting diodes (LEDs) during propagation.

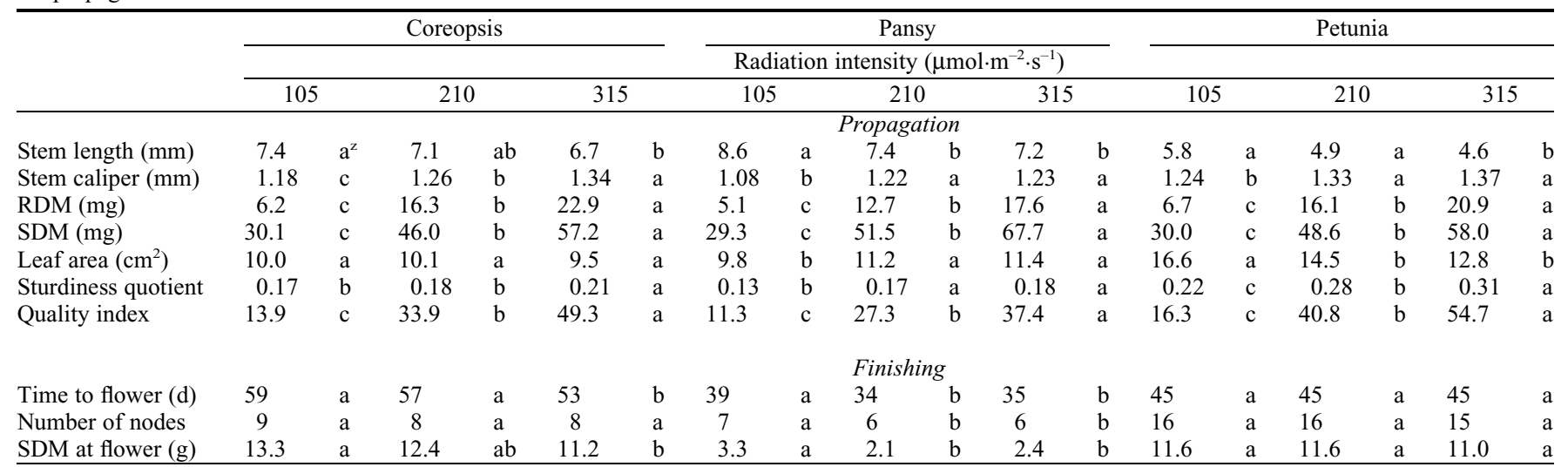

${ }^{\mathrm{z}}$ Means sharing a letter within a species are not statistically different by Tukey's honest significant difference test at $P \leq 0.05$.

Table 4. Propagation ( $28 \mathrm{~d}$ after germination) and finishing (transplanted $28 \mathrm{~d}$ after germination) data for the main effect of radiation quality including stem length, stem caliper, leaf area, root (RDM) and shoot dry mass (SDM), sturdiness quotient, quality index, time to flower, number of nodes below the first open flower, and SDM at flowering for coreopsis (Coreopsis grandiflora 'Sunfire'), pansy (Viola $\times$ wittrockiana 'Matrix Yellow'), and petunia (Petunia $\times$ hybrida 'Purple Wave') seedlings grown under radiation quality ratios (\%) of red:blue 87:13 $\left(\mathrm{R}_{87}: \mathrm{B}_{13}\right)$, red:far-red:blue 84:7:9 $\left(\mathrm{R}_{84}: \mathrm{FR}_{7}: \mathrm{B}_{9}\right)$, or red:green:blue $74: 18: 8\left(\mathrm{R}_{74}\right.$ : $\mathrm{G}_{18}: \mathrm{B}_{8}$ ) delivered from sole-source light-emitting diodes (LEDs) during propagation.

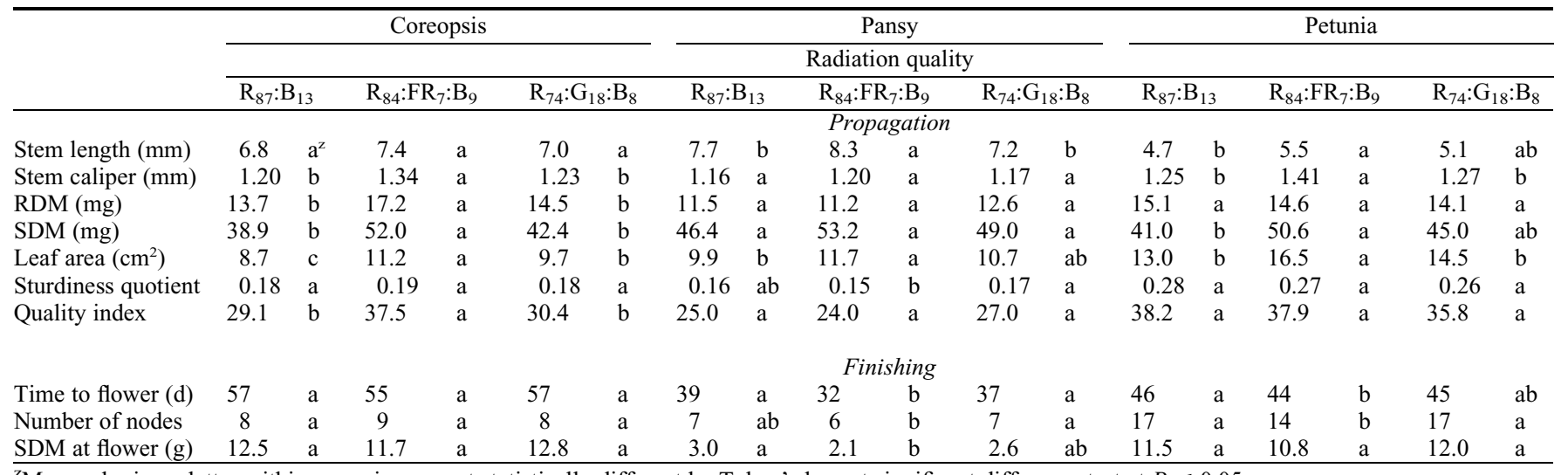

${ }^{\mathrm{z}}$ Means sharing a letter within a species are not statistically different by Tukey's honest significant difference test at $P \leq 0.05$.

$\mathrm{R}_{84}: \mathrm{FR}_{7}: \mathrm{B}_{9}$ compared with $\mathrm{R}_{87}: \mathrm{B}_{13}$ and $\mathrm{R}_{74}$ : $\mathrm{G}_{18}: \mathrm{B}_{8}$, respectively (Table 4).

$R D M$ and $S D M$. As radiation intensity increased, both RDM and SDM increased for all three species (Table 3). For example, as radiation intensity increased from 105 to 315 $\mu \mathrm{mol} \cdot \mathrm{m}^{-2} \cdot \mathrm{s}^{-1}, \mathrm{RDM}$ of coreopsis, pansy, and petunia increased $269 \%, 245 \%$, and $212 \%$, respectively. Likewise, SDM of coreopsis, pansy, and petunia increased $90 \%, 131 \%$, and
$93 \%$, respectively, as radiation intensity increased from 105 to $315 \mu \mathrm{mol} \cdot \mathrm{m}^{-2} \cdot \mathrm{s}^{-1}$. For coreopsis, RDM increased $26 \%$ and $19 \%$ under $\mathrm{R}_{84}: \mathrm{FR}_{7}: \mathrm{B}_{9}$ compared with $\mathrm{R}_{87}: \mathrm{B}_{13}$ and $\mathrm{R}_{74}: \mathrm{G}_{18}: \mathrm{B}_{8}$, respectively (Table 4 ). Additionally, 
SDM of coreopsis increased $33 \%$ and $22 \%$ under $\mathrm{R}_{84}: \mathrm{FR}_{7}: \mathrm{B}_{9}$ compared with $\mathrm{R}_{87}: \mathrm{B}_{13}$ and $\mathrm{R}_{74}: \mathrm{G}_{18}: \mathrm{B}_{8}$, respectively (Table 4 ). Likewise, SDM of petunia increased $23 \%$ under $\mathrm{R}_{84}$ : $\mathrm{FR}_{7}: \mathrm{B}_{9}$ compared with $\mathrm{R}_{87}: \mathrm{B}_{13}$.

Quality parameters. While radiation quality had little effect on quality parameters, seedlings grown under higher radiation intensities displayed higher SQ and QI values for all three species (Table 3). For example, SQ values for coreopsis, pansy, and petunia were $24 \%, 38 \%$, and $41 \%$ higher, respectively, under the radiation intensity of 315 compared with $105 \mu \mathrm{mol} \cdot \mathrm{m}^{-2} \cdot \mathrm{s}^{-1}$. Similarly, QI values for all three species increased as radiation intensity increased (Table 3). Quality index values for coreopsis, pansy, and petunia were $255 \%, 231 \%$, and $236 \%$ higher, respectively, under the radiation intensity of 315 compared with $105 \mu \mathrm{mol} \cdot \mathrm{m}^{-2} \cdot \mathrm{s}^{-1}$. In terms of radiation quality, QI values for coreopsis were $29 \%$ and $23 \%$ higher under
$\mathrm{R}_{84}: \mathrm{FR}_{7}: \mathrm{B}_{9}$ compared with $\mathrm{R}_{87}: \mathrm{B}_{13}$ and $\mathrm{R}_{74}$ : $\mathrm{G}_{18}: \mathrm{B}_{8}$, respectively (Table 4).

Nutrient concentration. For all three species, both macro- and micronutrient concentrations were generally lower as radiation intensity increased (Tables 5 and 6). In terms of radiation quality, at a radiation intensity of $315 \mu \mathrm{mol} \cdot \mathrm{m}^{-2} \cdot \mathrm{s}^{-1}$, petunia accumulated $30 \%$, $19 \%, 18 \%, 34 \%$, and $25 \%$ more sulfur (S), $\mathrm{Ca}, \mathrm{Mg}, \mathrm{Cu}$, and $\mathrm{Zn}$, respectively, under $\mathrm{R}_{84}$ : $\mathrm{FR}_{7}: \mathrm{B}_{9}$ compared with $\mathrm{R}_{74}: \mathrm{G}_{18}: \mathrm{B}_{8}$ (Tables 5 and 6). However, in pansy, the highest nutrient concentrations were often observed under $\mathrm{R}_{87}$ : $\mathrm{B}_{13}$ (Tables 5 and 6). Specifically, at a radiation intensity of $105 \mu \mathrm{mol} \cdot \mathrm{m}^{-2} \cdot \mathrm{s}^{-1}$, pansy accumulated $12 \%$ more $\mathrm{S}$ and $\mathrm{Mg}$ under $\mathrm{R}_{87}$ : $\mathrm{B}_{13}$ compared with $\mathrm{R}_{84}: \mathrm{FR}_{7}: \mathrm{B}_{9}$. Additionally, at a radiation intensity of $315 \mu \mathrm{mol} \cdot \mathrm{m}^{-2} \cdot \mathrm{s}^{-1}$, pansy accumulated $19 \%$ more $S$ under $R_{87}: B_{13}$ compared with $\mathrm{R}_{74}: \mathrm{G}_{18}: \mathrm{B}_{8}$. Coreopsis displayed a similar trend to pansy at a radiation intensity of $105 \mu \mathrm{mol} \cdot \mathrm{m}^{-2} \cdot \mathrm{s}^{-1}$, with $9 \%$ more $\mathrm{P}$ and $20 \%$ more $\mathrm{Mn}$ for seedlings under $\mathrm{R}_{87}: \mathrm{B}_{13}$ compared with $\mathrm{R}_{84}: \mathrm{FR}_{7}: \mathrm{B}_{9}$ and $\mathrm{R}_{74}: \mathrm{G}_{18}: \mathrm{B}_{8}$, respectively (Tables 5 and 6).

Finishing. Pansy flowered an average of 5 and $4 \mathrm{~d}$ earlier when seedlings were grown at a radiation intensity of 210 or $315 \mu \mathrm{mol} \cdot \mathrm{m}^{-2} \cdot \mathrm{s}^{-1}$, respectively, compared with $105 \mu \mathrm{mol} \cdot \mathrm{m}^{-2} \cdot \mathrm{s}^{-1}$ (Table 3). Likewise, coreopsis flowered an average of $6 \mathrm{~d}$ earlier when seedlings were propagated at a radiation intensity of 315 compared with $105 \mu \mathrm{mol} \cdot \mathrm{m}^{-2} \cdot \mathrm{s}^{-1}$. Additionally, a decrease in TTF was observed in pansy and petunia seedlings grown under $\mathrm{R}_{84}: \mathrm{FR}_{7}: \mathrm{B}_{9}$ during propagation (Table 4 ). Pansy seedlings grown under $\mathrm{R}_{84}: \mathrm{FR}_{7}: \mathrm{B}_{9}$ flowered an average of 7 and $5 \mathrm{~d}$ earlier compared with $\mathrm{R}_{87}: \mathrm{B}_{13}$ and $\mathrm{R}_{74}: \mathrm{G}_{18}: \mathrm{B}_{8}$, respectively. Similarly, petunia seedlings grown under $\mathrm{R}_{84}: \mathrm{FR}_{7}: \mathrm{B}_{9}$ flowered an average of $2 \mathrm{~d}$ earlier compared with $\mathrm{R}_{87}: \mathrm{B}_{13}$.

For coreopsis and pansy, SDM at flower was $16 \%$ and $27 \%$ lower, respectively, when

Table 5. Macronutrient concentration [percent dry mass (DM)] of coreopsis (Coreopsis grandiflora 'Sunfire'), pansy (Viola $\times$ wittrockiana 'Matrix Yellow'), and

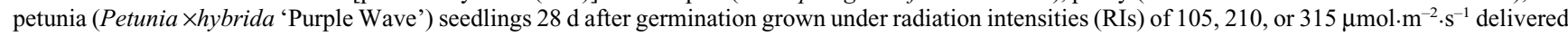
from sole-source light-emitting diodes (LEDs) with radiation quality (RQ) ratios $(\%)$ of red:blue 87:13 ( $\left.\mathrm{R}_{87}: \mathrm{B}_{13}\right)$, red:far-red:blue $84: 7: 9\left(\mathrm{R}_{84}: \mathrm{FR}_{7}: \mathrm{B}_{9}\right)$, or red: green:blue $74: 18: 8\left(\mathrm{R}_{74}: \mathrm{G}_{18}: \mathrm{B}_{8}\right)$.

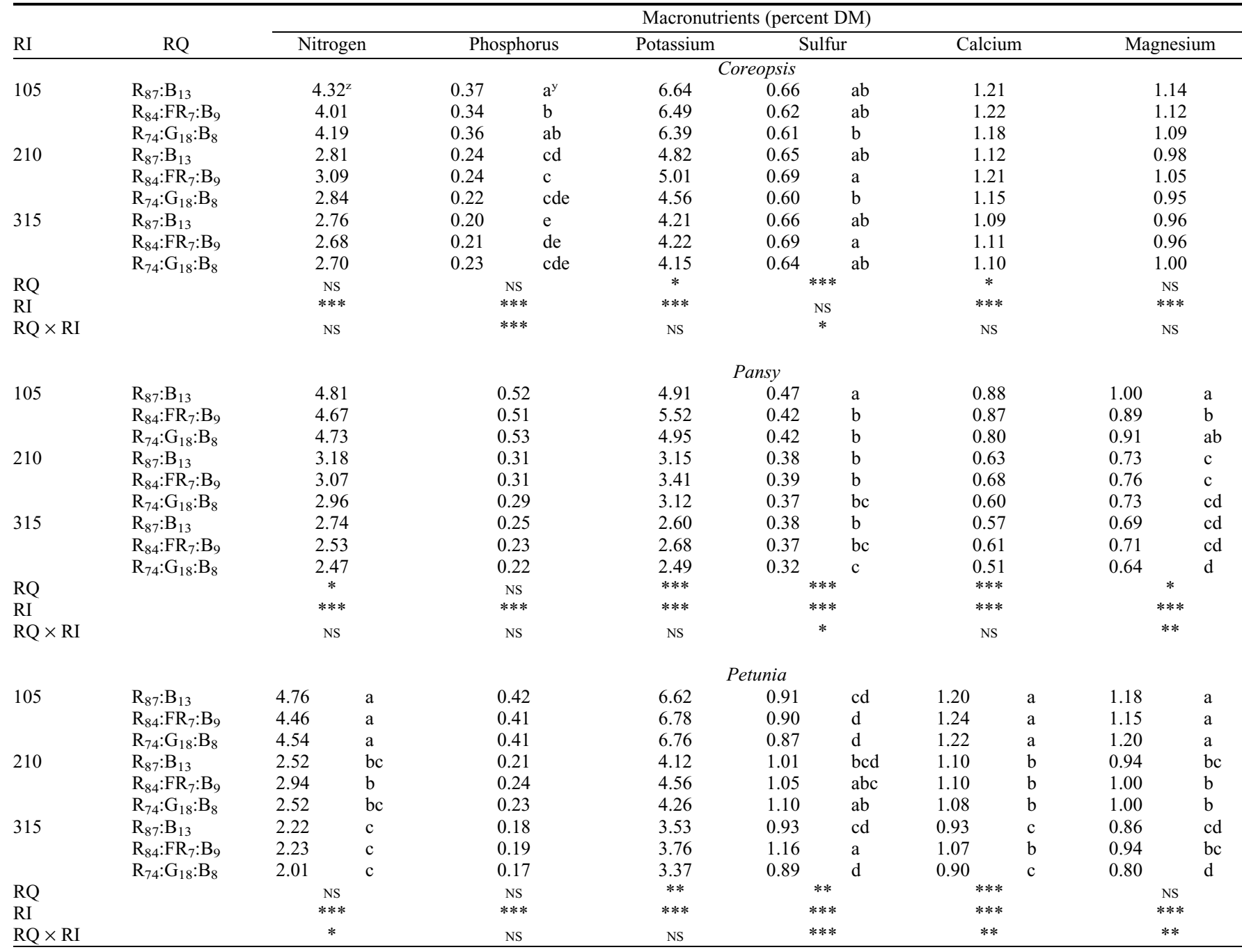

${ }^{\mathrm{z}}$ Mean values are based on a representative sample from each treatment across three experimental replications.

${ }^{\mathrm{y}}$ Means sharing a letter are not statistically different by Tukey's honest significant difference test at $P \leq 0.05$. Means with no lettering were found to have no significant interaction between RQ and RI.

Ns, *, **, ***Nonsignificant or significant at $P \leq 0.05,0.01$, or 0.001 , respectively. 
Table 6. Micronutrient concentrations ( $\left.\mathrm{mg} \cdot \mathrm{kg}^{-1}\right)$ of coreopsis (Coreopsis grandiflora 'Sunfire'), pansy (Viola $\times$ wittrockiana 'Matrix Yellow'), and petunia (Petunia $\times$ hybrida 'Purple Wave') seedlings $28 \mathrm{~d}$ after germination grown under radiation intensities (RIs) of 105,210, or $315 \mu \mathrm{mol} \cdot \mathrm{m}^{-2} \cdot \mathrm{s}^{-1}$ delivered from sole-source light-emitting diodes (LEDs) with radiation quality (RQ) ratios $(\%)$ of red:blue $87: 13\left(\mathrm{R}_{87}: \mathrm{B}_{13}\right)$, red:far-red:blue $84: 7: 9\left(\mathrm{R}_{84}: \mathrm{FR}_{7}: \mathrm{B}_{9}\right)$, or red: green:blue $74: 18: 8\left(\mathrm{R}_{74}: \mathrm{G}_{18}: \mathrm{B}_{8}\right)$.

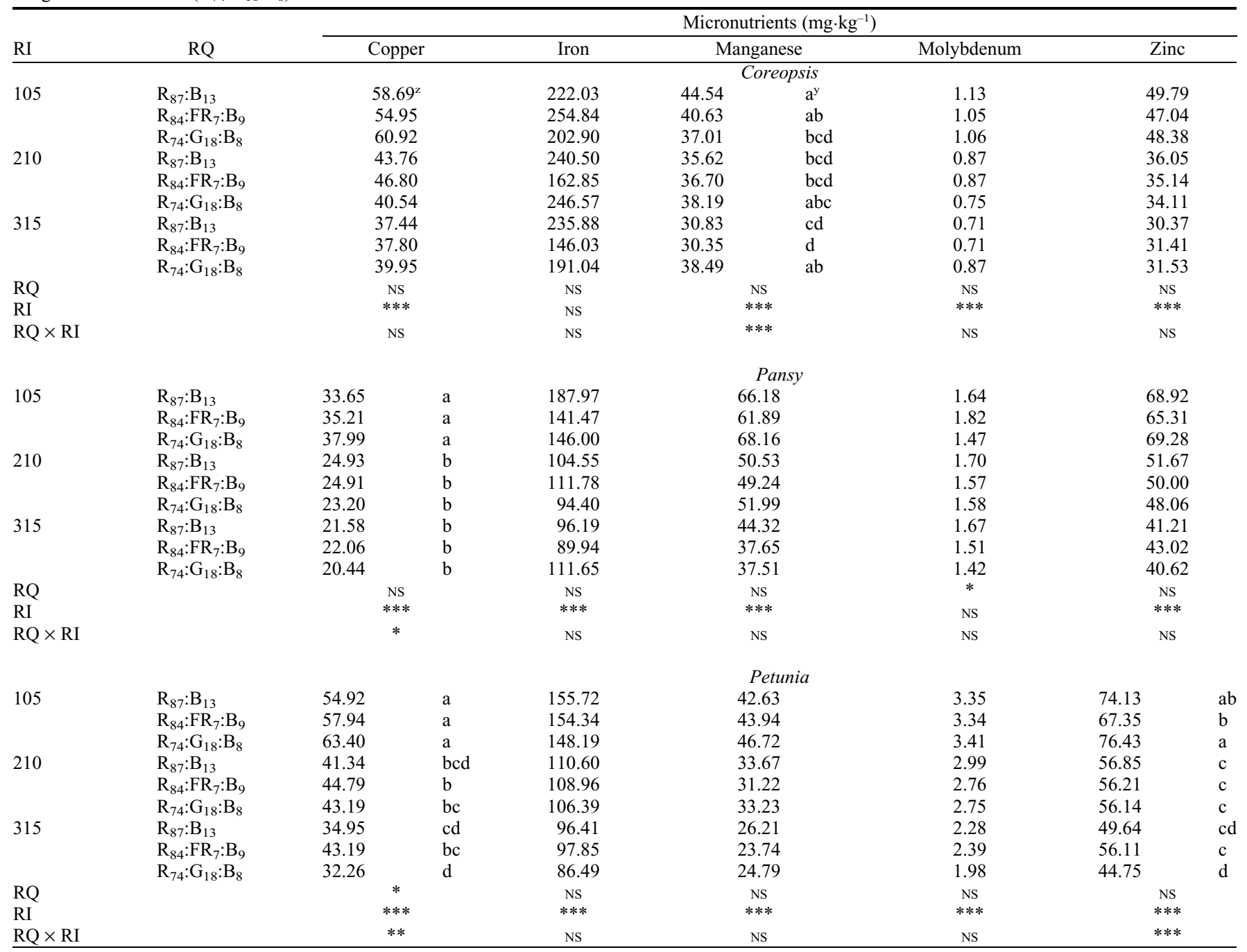

${ }^{\mathrm{z}}$ Mean values are based on a representative sample from each treatment across three experimental replications.

${ }^{\mathrm{y}}$ Means sharing a letter are not statistically different by Tukey's honest significant difference test at $P \leq 0.05$. Means with no lettering were found to have no significant interaction between RQ and RI.

NS, $*, * *, * * *$ Nonsignificant or significant at $P \leq 0.05,0.01$, or 0.001 , respectively.

seedlings were propagated at a radiation intensity of 315 compared with $105 \mu \mathrm{mol} \cdot \mathrm{m}^{-2} \cdot \mathrm{s}^{-1}$ (Table 3). Regarding radiation quality, for pansy and petunia, the number of nodes at first flower was lower when seedlings were grown under $\mathrm{R}_{84}: \mathrm{FR}_{7}: \mathrm{B}_{9}$ (Table 4). For example, when pansy seedlings were grown under $\mathrm{R}_{84}: \mathrm{FR}_{7}: \mathrm{B}_{9}$, three fewer nodes were present at first flower compared with the other two radiation quality treatments. Similar results were observed for dry mass in pansy, with seedlings grown under $\mathrm{R}_{84}: \mathrm{FR}_{7}: \mathrm{B}_{9}$ possessing a $30 \%$ lower SDM at flower compared with $\mathrm{R}_{87}: \mathrm{B}_{13}$ (Table 4).

\section{Discussion}

A high-quality bedding plant seedling is one that has a compact habit, high RDM and SDM, and thick stem diameter (Oh et al., 2010; Pramuk and Runkle, 2005; Randall and Lopez, 2014). These qualitative parameters ultimately lead to seedlings that are more easily processed, shipped, and mechanically transplanted, which is desired by growers (Pramuk and Runkle, 2005). When produced in a growth chamber environment under SSL, we found that high radiation intensities and radiation qualities of $\mathrm{R}_{87}: \mathrm{B}_{13}$ and $\mathrm{R}_{74}: \mathrm{G}_{18}: \mathrm{B}_{8}$ generally led to compact seedlings with a shorter stem length and smaller leaf area compared with those grown under lower radiation intensities or with the inclusion of far-red wavelengths. High radiation intensities have been found to reduce the level of endogenous gibberellins (GAs) within higher plants, ultimately leading to reduced stem elongation and a more compact habit (Graebe, 1987; Potter et al., 1999). Thus, the compact seedling growth observed under higher radiation intensities was likely due to decreased GA levels. In the greenhouse, Lopez and Runkle (2008) reported comparable results as the shoot height of petunia
'Tiny Tunia Violet Ice', 'Double Wave Spreading Rose', and 'Supertunia Mini Purple' cuttings was $40 \%, 34 \%$, and $55 \%$ taller, respectively, as the DLI decreased from 5.9 to $1.2 \mathrm{~mol} \cdot \mathrm{m}^{-2} \cdot \mathrm{d}^{-1}$ with a $12 \mathrm{~h}$ photoperiod.

Far-red radiation is known to have a significant effect on promoting extension growth and leaf expansion (Downs and Thomas, 1982). Phytochromes are the photoreceptors responsible for detecting changes in the red:far-red (R:FR) ratio. In response to a lower R:FR ratio, many plants will display morphological changes such as increased stem elongation, larger leaf area, and thinner leaves, a response commonly referred to as shade avoidance (Franklin and Whitelam, 2005; Park and Runkle, 2017; Zhang and Folta, 2012). Park and Runkle (2017) found stem length of geranium 'Pinto Premium Orange Bicolor', petunia 'Wave Blue', snapdragon 'Trailing Candy Showers Yellow', and impatiens 'Super Elfin XP Red' seedlings 
displayed an inverse linear relationship with the estimated phytochrome photoequilibrium, which serves as an indicator of the relative amount of active phytochrome in plants, according to methods described by Sager et al. (1988). Specifically, as the estimated phytochrome photoequilibrium increased, stem length was shorter. Additionally, they found that leaf expansion was promoted for some species under a low R: FR ratio, as long as the radiation intensity was sufficient for growth. In the present study, the addition of FR radiation imbalanced the R:FR ratio under $\mathrm{R}_{84}: \mathrm{FR}_{7}: \mathrm{B}_{9}(\mathrm{R}$ : $\mathrm{FR}=9.3$ ), and seedlings exhibited increased stem elongation and leaf area compared with $\mathrm{R}_{87}: \mathrm{B}_{13}$ and $\mathrm{R}_{74}: \mathrm{G}_{18}: \mathrm{B}_{8}$ as a result.

Blue radiation has been shown to inhibit growth for a variety of species (Cosgrove, 1981; Runkle and Heins, 2001). This is likely due to the blue radiation photoreceptor cryptochrome acting on one or more steps in the process of cell enlargement (Cosgrove, 1981; Kigel and Cosgrove, 1991; Runkle and Heins, 2001). Excessive hypocotyl elongation of seedlings has been reported under LED SSL containing high proportions of red radiation and little to no blue radiation (Hoenecke et al., 1992). Thus, blue radiation may be essential under SSL to minimize stem elongation and produce compact seedlings (Hoenecke et al., 1992; Wollaeger and Runkle, 2014).

Suppression of leaf area expansion under an increased percentage of blue radiation has previously been observed for petunia 'Dreams Midnight', impatiens 'Super Elfin XP Blue Pearl', and vinca 'Titan Red Dark' seedlings (Randall and Lopez, 2014). Wollaeger and Runkle (2015) found that $\approx 10 \mu \mathrm{mol} \cdot \mathrm{m}^{-2} \cdot \mathrm{s}^{-1}$ of blue radiation, in a spectrum of predominately red radiation, was sufficient to inhibit extension growth and leaf area expansion for impatiens 'Super Elfin XP Red', petunia 'Wave Pink', salvia 'Vista Red', and tomato (Solanum lycopersicum 'Early Girl') seedlings. This coincides with our findings in the present study, where petunia seedlings grown under lower radiation intensities displayed increased leaf area expansion and stem elongation under the radiation qualities of $\mathrm{R}_{84}: \mathrm{FR}_{7}$ : $\mathrm{B}_{9}$ and $\mathrm{R}_{74}: \mathrm{G}_{18}: \mathrm{B}_{8}$ compared with $\mathrm{R}_{87}: \mathrm{B}_{13}$ (data not shown). Under the radiation qualities of $\mathrm{R}_{84}: \mathrm{FR}_{7}: \mathrm{B}_{9}$ and $\mathrm{R}_{74}: \mathrm{G}_{18}: \mathrm{B}_{8}$ at a radiation intensity of $105 \mu \mathrm{mol} \cdot \mathrm{m}^{-2} \cdot \mathrm{s}^{-1}$, the intensity of blue radiation was $\approx 9$ and $8 \mu \mathrm{mol} \cdot \mathrm{m}^{-2} \cdot \mathrm{s}^{-1}$, respectively. However, the intensity of blue radiation under $\mathrm{R}_{87}: \mathrm{B}_{13}$, where differences in stem elongation and leaf area amongst radiation intensities were not observed, was $\approx 14$ $\mu \mathrm{mol} \cdot \mathrm{m}^{-2} \cdot \mathrm{s}^{-1}$ at a radiation intensity of 105 $\mu \mathrm{mol} \cdot \mathrm{m}^{-2} \cdot \mathrm{s}^{-1}$. Franklin (2008) found that reductions in radiation intensity, specifically with regard to blue wavelengths, can elicit physiological responses characteristic of a low R:FR ratio. Therefore, it is likely that with lower radiation intensities, seedlings grown under reduced percentages of blue radiation were not exposed to a sufficient quantity to inhibit responses connected to shade avoidance.

For many commercial LED arrays, a small percentage of green wavelengths is com- monly included in the spectrum to facilitate crop assessment and provide a more comfortable environment for workers in controlled environments. While green radiation has traditionally been deemed as less efficient than blue or red radiation for the promotion of plant growth, recent studies have found that green wavelengths may penetrate deeper into leaves and canopies to improve productivity and manipulate stomatal aperture (Smith et al., 2017). Additionally, green radiation absorbed by cryptochrome has been found to stimulate a response similar to shade avoidance, as these wavelengths can reverse the effects of blue radiation-inhibited hypocotyl elongation (Smith et al., 2017; Zhang and Folta, 2012). While this mechanism is not fully understood, the addition of green radiation may have also resulted in the increased leaf area and stem elongation observed with petunia under $\mathrm{R}_{74}: \mathrm{G}_{18}: \mathrm{B}_{8}$ compared with $\mathrm{R}_{87}: \mathrm{B}_{13}$ at low radiation intensities (data not shown). Additionally, the larger leaf area observed with coreopsis under $\mathrm{R}_{74}: \mathrm{G}_{18}: \mathrm{B}_{8}$ compared with $\mathrm{R}_{87}: \mathrm{B}_{13}$ was likely a similar response.

For all three species in the present study, both RDM and SDM increased under higher radiation intensities. This observation is well documented, with many greenhouse studies reporting an increased DLI leading to increased biomass accumulation and growth rate (Graper and Healy, 1991, 1992; Lopez and Runkle, 2008; Pramuk and Runkle, 2005). For example, Oh et al. (2010) found that pansy 'Delta Premium Yellow' and petunia 'Madness Red' seedlings displayed a linear increase in SDM under increasing DLIs. In the present study, both RDM and SDM for all three species continued to significantly increase up to the highest radiation intensity of $315 \mu \mathrm{mol} \cdot \mathrm{m}^{-2} \cdot \mathrm{s}^{-1}$. Thus, while it is generally recommended that seedlings be grown at a DLI of 10 to $12 \mathrm{~mol} \cdot \mathrm{m}^{-2} \cdot \mathrm{d}^{-1}$ (175 to $210 \mu \mathrm{mol} \cdot \mathrm{m}^{-2} \cdot \mathrm{s}^{-1}$ with a $16 \mathrm{~h}$ photoperiod), potential increases in seedling quality and a decrease in production time may be possible under higher radiation intensities. However, whether increased radiation intensity provides an economic benefit for the production of bedding plant seedlings remains uncertain.

Root dry mass and SDM of seedlings grown under $\mathrm{R}_{84}: \mathrm{FR}_{7}: \mathrm{B}_{9}$ were often higher than seedlings grown under $R_{87}: B_{13}$ or $R_{74}$ : $\mathrm{G}_{18}: \mathrm{B}_{8}$. Wollaeger and Runkle (2014) suggest the primary role of radiation quality on biomass accumulation in tomato 'Early Girl', salvia 'Vista Red', impatiens 'Super Elfin XP Red', and petunia 'Wave Pink' seedlings can be attributed to an increase in leaf area. As leaf area increases, the potential for biomass accumulation also increases due to a greater potential for radiation interception. Leaf area was largest under $\mathrm{R}_{84}: \mathrm{FR}_{7}: \mathrm{B}_{9}$ for all three species in the present study. Therefore, it is likely that the addition of far-red wavelengths allowed for an increase in leaf area by lowering the R:FR ratio, ultimately leading to increased radiation interception and SDM accumulation. In addition to increasing leaf area, the inclusion of far-red radiation may have enhanced the total photosynthetically active radiation $(P A R)$ available to the seedlings. Li and Kubota (2009) found that fluorescent white radiation supplemented with far-red LEDs led to increased fresh and dry weight of lettuce (Lactuca sativa 'Red Cross') compared with fluorescent radiation alone at the same PPFD. Increasing the quantum yield with far-red radiation has also been shown to increase whole-plant net assimilation for multiple bedding plant species (Park and Runkle, 2016, 2017). Recent studies have also shown that photosynthetic activity in photosystem II (PSII) can be stimulated by far-red radiation (Pettai et al., 2005; Thapper et al., 2009; Zhen and van Iersel, 2017). In the present study, target radiation intensities were achieved by accounting for $P A R$ rather than total photon flux (TPF; 400-800 nm). Thus, the radiation intensities established using the $\mathrm{R}_{84}: \mathrm{FR}_{7}: \mathrm{B}_{9}$ LEDs did not account for the additional $7 \%$ far-red radiation $\left(\approx 7-22 \mu \mathrm{mol} \cdot \mathrm{m}^{-2} \cdot \mathrm{s}^{-1}\right)$. As the impacts of far-red radiation continue to be researched, future studies may need to use $T P F$ rather than PPFD to measure the amount of radiation available for photosynthetic activity.

The QI provides an objective, integrated, and quantitative measurement for further evaluation of seedling quality, with higher values indicating higher quality (Currey et al., 2013; Randall and Lopez, 2014). The highest quality seedlings were consistently produced under higher radiation intensities, with little to no effect from radiation quality. This increased quality was primarily due to seedlings grown under higher radiation intensities exhibiting shorter stems, larger stem calipers, and higher RDM and SDM.

Both macro- and micronutrient concentrations were generally lowest in seedlings grown under high radiation intensities. Similar to observations made by Gerovac et al. (2016), this trend may be the result of a dilution of nutrients due to the higher SDM consistently found at higher radiation intensities (Table 3). Kuehny et al. (1991) previously investigated this effect of nutrient dilution in chrysanthemum (Chrysanthemum $\times$ morifolium 'Fiesta') and found that foliar concentrations of nutrients were lower under increased irradiance and an elevated $\mathrm{CO}_{2}$ concentration. However, when data were expressed on a starch-free dry weight basis, the authors found that most of the differences observed between treatments were no longer apparent (Kuehny et al., 1991). Therefore, it is plausible that seedlings grown under the lower radiation intensities in the present study were more nutrient dense simply due to reduced biomass accumulation.

Radiation quality also influenced nutrient concentration. Specifically, for both coreopsis and pansy, select macro- and micronutrients were significantly higher under $R_{87}: B_{13}$ compared with $\mathrm{R}_{84}: \mathrm{FR}_{7}: \mathrm{B}_{9}$ and $\mathrm{R}_{74}: \mathrm{G}_{18}: \mathrm{B}_{8}$. An increased percentage of blue radiation has been found to result in higher concentrations of essential elements in microgreens (Kopsell 
and Sams, 2013; Kopsell et al., 2014). Kopsell et al. (2014) proposed that blue radiation plays a dominant role in regulating processes linked to nutrient content, including membrane permeability, proton pumping, and ion channel activities. Additionally, blue radiation has been found to play a primary role in the regulation of stomatal opening (Kinoshita et al., 2001; Van Ieperen et al., 2012), which may directly affect nutrient uptake via transpirationallyinduced mass flow. Therefore, the increase in select macro- and micronutrients for coreopsis and pansy under $\mathrm{R}_{87}: \mathrm{B}_{13}$ LEDs may have resulted from the $4 \%$ to $5 \%$ increase in blue radiation compared with the other two treatments.

The effects of DLI on flowering in greenhouse-grown bedding plant species is well documented (Faust et al., 2005; Oh et al., 2010; Pramuk and Runkle, 2005). Pramuk and Runkle (2005) found that TTF for celosia 'Gloria Mix', impatiens 'Accent Red', salvia 'Vista Red', marigold 'Bonanza Yellow', and pansy 'Crystal Bowl Yellow' decreased as the greenhouse DLI increased during propagation. Additionally, these authors reported that the percentage of impatiens 'Accent Red' and marigold 'Bonanza Yellow' seedlings with visible bud at transplant also increased as the DLI increased (Pramuk and Runkle, 2005). Lopez and Runkle (2008) found a similar decrease in TTF for petunia 'Tiny Tunia Violet' and 'Supertunia Mini Purple' as the greenhouse DLI increased from 1.4 to $10.7 \mathrm{~mol} \cdot \mathrm{m}^{-2} \cdot \mathrm{d}^{-1}$ during cutting propagation. Plants exhibiting a facultative irradiance response tend to flower earlier and develop fewer nodes before flower initiation when exposed to higher radiation environments (Erwin et al., 2017). In the present study, both coreopsis and pansy possessed a facultative irradiance response as exhibited by their earlier flowering and lower number of nodes at flower. One limitation to this conclusion may have been increased leaf temperatures under higher radiation intensities. However, while leaf temperature was not measured in the present study, similar research (data not shown) has found that leaf temperature of petunia 'Dreams Midnight' differed less than $0.5^{\circ} \mathrm{C}$ between sole-source LED radiation intensities of 150 and 300 $\mu \mathrm{mol} \cdot \mathrm{m}^{-2} \cdot \mathrm{s}^{-1}$ and varying red:blue radiation ratios. Thus, the earlier flowering response observed for coreopsis and pansy was likely due to differences in radiation intensity rather than leaf temperature.

With coreopsis and pansy, lower SDM at first flower was observed as the radiation intensity increased. Hutchinson et al. (2012) found similar results: TTF for Angelonia angustifolia 'AngelMist White Cloud' and Osteospermum ecklonis 'Voltage Yellow' decreased linearly as the DLI during propagation increased, with lower SDM values observed alongside this decrease in days to flower. Earlier flowering may be beneficial when seedlings are produced with the intent for finishing in small containers, while a delay in flowering would likely be preferred for seedlings intended for large containers, as this would encourage increased vegetative development (Hutchinson et al., 2012; Mattson and Erwin, 2005).

For pansy, TTF significantly decreased when seedlings were grown under $\mathrm{R}_{84}: \mathrm{FR}_{7}$ : $\mathrm{B}_{9}$ compared with the other radiation quality treatments. Far-red radiation has been shown to have a significant effect on the promotion of flowering for plants with a long-day photoperiodic response (Downs and Thomas, 1982). However, species with a long-day photoperiodic response may respond differently to the inclusion or exclusion of far-red radiation. For some species, the response to far-red radiation is specific to flower development, while in others the effect is specific to flower induction (Runkle and Heins, 2001; Thomas and Vince-Prue, 1997). For coreopsis and petunia, it is likely that far-red radiation was unnecessary for flower induction, leading to only minor differences observed in TTF with the inclusion of these wavelengths. However, the inclusion of farred radiation led to a significant decrease in TTF for pansy, leading to the assumption that flower induction was accelerated during propagation under $\mathrm{R}_{84}: \mathrm{FR}_{7}: \mathrm{B}_{9}$. Park and Runkle (2017) found similar results in that only one of two species evaluated with a long-day photoperiodic response was responsive to the inclusion of far-red radiation during seedling production for earlier flowering. However, both species displayed increased growth and characteristic photomorphogenic responses to the inclusion of far-red radiation. Thus, these authors concluded that the regulation of flowering and photomorphogenic responses from far-red radiation are independent within the plant (Park and Runkle, 2017). While all three species displayed photomorphogenic responses to far-red radiation in the present study, pansy was the only species that possessed a flowering response. Thus, the characterization and selection of species responses to the inclusion or exclusion of various wavelengths of radiation is critical when designing SSL applications.

Based on our results, radiation intensity appears to be the dominant factor influencing seedling quality under SSL. While radiation quality can induce a variety of photomorphogenic responses, the highest quality seedlings for all three species were consistently produced under the radiation intensity of 315 $\mu \mathrm{mol} \cdot \mathrm{m}^{-2} \cdot \mathrm{s}^{-1}$. Thus, for most production applications, priority should be placed on $P P F D$ rather than spectral composition. However, it is important to note that the LED arrays used for this study were commercially available fixtures with spectral ratios predetermined by the manufacturer. While the prospect of reducing the radiation intensity under optimized spectra does exist, further research is required to elucidate these spectral responses for seedling production. Nevertheless, far-red wavelengths included in the spectrum may be beneficial if accelerated flowering upon transplant is desired for long-day plants, but this response is highly dependent on species. Therefore, these results provide further information regarding the specific radiation parameters from commercially available LEDs necessary to produce high-quality bedding plant seedlings under SSL.

\section{Literature Cited}

Barnes, C., T. Tibbitts, J. Sager, G. Deitzer, D. Bubenheim, G. Koerner, and B. Bugbee. 1993. Accuracy of quantum sensors measuring yield photon flux and photosynthetic photon flux. HortScience 28:1197-1200.

Cope, K.R., M.C. Snowden, and B. Bugbee. 2014. Photobiological interactions of blue light and photosynthetic photon flux: Effects of monochromatic and broad-spectrum light sources. Photochem. Photobiol. 90:574-584.

Cosgrove, D.J. 1981. Rapid suppression of growth by blue light. Plant Physiol. 67:584-590.

Currey, C.J., A.P. Torres, R.G. Lopez, and D.F. Jacobs. 2013. The quality index - a new tool for integrating quantitative measurements to assess quality of young floriculture plants. Acta Hort. 1000:385-391.

Currey, C.J., R.G. Lopez, and N.S. Mattson. 2011 Flower induction of annuals. Purdue Ext. Bul. H0-249-W.

Downs, R.J. and J.F. Thomas. 1982. Phytochrome regulation of flowering in the long-day plant, Hyoscyamus niger. Plant Physiol. 70:898-900.

Erwin, J., N. Mattson, and R. Warner. 2017. Light effects on bedding plants, p. 119-134. In: R. Lopez and E. Runkle (eds.). Light management in controlled environments. Meister Media Worldwide, Willoughby, $\mathrm{OH}$.

Faust, J.E., V. Holcombe, N.C. Rajapakse, and D.R. Layne. 2005. The effect of daily light integral on bedding plant growth and flowering. HortScience 40:645-649.

Franklin, K.A. 2008. Shade avoidance. New Phytol. 179:930-944.

Franklin, K.A. and G.C. Whitelam. 2005. Phytochromes and shade-avoidance responses in plants. Ann. Bot. 96:169-175.

Frantz, J.M. 2013. Uptake efficiency of phosphorus in different light environments by zinnia (Zinnia elegans) and vinca (Catharanthus roseus). HortScience 48:594-600.

Gerovac, J.R., J.K. Craver, J.K. Boldt, and R.G. Lopez. 2016. Radiation intensity and quality from sole-source light-emitting diodes impact growth, morphology, and nutrient content of Brassica microgreens. HortScience 5:497-503.

Graebe, J.E. 1987. Gibberellin biosynthesis and control. Annu. Rev. Plant Physiol. 38:419-465.

Graper, D.F. and W. Healy. 1991. High pressure sodium irradiation and infrared radiation accelerate petunia seedling growth. J. Amer. Soc. Hort. Sci. 116:435-438.

Graper, D.F. and W. Healy. 1992. Modification of petunia seedling carbohydrate partitioning by irradiance. J. Amer. Soc. Hort. Sci. 117:477480.

Hoenecke, M.E., R.J. Bula, and T.W. Tibbits 1992. Importance of 'blue' photon levels for lettuce seedlings grown under red-light-emitting diodes. HortScience 27:427-430.

Hutchinson, V.A., C.J. Currey, and R.G. Lopez. 2012. Photosynthetic daily light integral during root development influences subsequent growth and development of several herbaceous annual bedding plants. HortScience 47:856860.

Kigel, J. and D.J. Cosgrove. 1991. Photoinhibition of stem elongation by blue and red light. Plant Physiol. 95:1049-1056.

Kinoshita, T., M. Doi, N. Suetsugu, T. Kagawa, M. Wada, and K. Shimazaki. 2001. Phot1 and 
phot2 mediate blue light regulation of stomatal opening. Nature 414:656-660.

Kopsell, D.A. and C.E. Sams. 2013. Increase in shoot tissue pigments, glucosinolates, and mineral elements in sprouting broccoli after exposure to short-duration blue light from light-emitting diodes. J. Amer. Soc. Hort. Sci. 138:31-37.

Kopsell, D.A., C.E. Sams, T.C. Barickman, and R.C. Morrow. 2014. Sprouting broccoli accumulate higher concentrations of nutritionally important metabolites under narrow-band light-emitting diode lighting. J. Amer. Soc. Hort. Sci. 139:469-477.

Kuehny, J.S., M.M. Peet, P.V. Nelson, and D.H. Willits. 1991. Nutrient dilution by starch in $\mathrm{CO}_{2}$-enriched chrysanthemum. J. Expt. Bot. 42:711-716.

Li, Q. and C. Kubota. 2009. Effects of supplemental radiation quality on growth and phytochemicals of baby leaf lettuce. Environ. Exp. Bot. 67:59-64.

Lopez, R., C. Currey, and E. Runkle. 2017. Light and young plants, p. 109-118. In: R. Lopez and E. Runkle (ed.). Light management in controlled environments. Meister Media Worldwide, Willoughby, $\mathrm{OH}$.

Lopez, R.G. and E.S. Runkle. 2008. Photosynthetic daily light integral during propagation influences rooting and growth of cuttings and subsequent development of New Guinea impatiens and petunia. HortScience 43:2052-2059.

Massa, G.D., H. Kim, R.M. Wheeler, and C.A. Mitchell. 2008. Plant productivity in response to LED lighting. HortScience 43:1951-1956.

Mattson, N.S. and J.E. Erwin. 2005. The impact of photoperiod and irradiance on flowering of several herbaceous ornamentals. Scientia Hort. 104:275-292.

Mitchell, C.A., A. Both, C.M. Bourget, J.F. Burr, C. Kubota, R.G. Lopez, R.C. Morrow, and E.S. Runkle. 2012. LEDs: The future of greenhouse lighting! Chronica Hort. 52:6-12.
Oh, W., E.S. Runkle, and R.M. Warner. 2010. Timing and duration of supplemental lighting during the seedling stage influence quality and flowering in petunia and pansy. HortScience 45:1332-1337.

Park, Y. and E.S. Runkle. 2016. Investigating the merit of including far-red radiation in the production of ornamental seedlings grown under sole-source lighting. Acta Hort. 1134:259-266.

Park, Y. and E.S. Runkle. 2017. Far-red radiation promotes growth of seedlings by increasing leaf expansion and whole-plant net assimilation. Environ. Expt. Bot. 136:41-49.

Pettai, H., V. Oja, A. Freiberg, and A. Lasik. 2005. Photosynthetic activity of far-red light in green plants. Biochim. Biophys. Acta 1708:311-321.

Potter, T.I., S.B. Rood, and K.P. Zanewich. 1999. Radiation intensity, gibberellin content and the resolution of shoot growth in Brassica. Planta 207:505-511.

Pramuk, L.A. and E.S. Runkle. 2005. Photosynthetic daily light integral during the seedling stage influences subsequent growth and flowering of Celosia, Impatiens, Salvia, Tagetes, and Viola. HortScience 40:1336-1339.

Randall, W.C. and R.G. Lopez. 2014. Comparison of supplemental lighting from high-pressure sodium lamps and light-emitting diodes during bedding plant seedling production. HortScience 49:589-595.

Randall, W.C. and R.G. Lopez. 2015. Comparison of bedding plant seedlings grown under solesource light-emitting diodes (LEDs) and greenhouse supplemental lighting from LEDs and high-pressure sodium lamps. HortScience 50:705-713.

Runkle, E.S. and R.D. Heins. 2001. Specific functions of red, far red, and blue light in flowering and stem extension of long-day plants. J. Amer. Soc. Hort. Sci. 126:275-282.

Sager, J.C., W.O. Smith, J.L. Edwards, and K.L. Cyr. 1988. Photosynthetic efficiency and phy- tochrome photoequilibria determination using spectral data. Trans. Amer. Soc. Agr. Eng. 31:1882-1889.

Smith, H.L., L. McAusland, and E.H. Murchie. 2017. Don't ignore the green light: Exploring diverse roles in plant processes. J. Expt. Bot. 68:2099-2110.

Stutte, G.W. 2009. Light-emitting diodes for manipulating the phytochrome apparatus. HortScience 44:231-234

Styer, R.C. 2003. Propagating seed crops, p. 151163. In: D. Hamrick (ed.). Ball redbook crop production: Vol. 2. 17th ed. Ball Publishing, Batavia, IL.

Thapper, A., F. Mamedov, F. Mokvist, L. Hammarstrom, and S. Styring. 2009. Defining the far-red limit of photosystem II in spinach. Plant Cell 21: 2391-2401.

Thomas, B. and D. Vince-Prue. 1997. Photoperiodism in plants. 2nd ed. Academic Press, London

Van Ieperen, W., A. Savvides, and D. Fanourakis. 2012. Red and blue light effects during growth on hydraulic and stomatal conductance in leaves of young cucumber plants. Acta Hort. 956:223-230.

Wollaeger, H.M. and E.S. Runkle. 2014. Producing commercial-quality ornamental seedlings under sole-source LED lighting. Acta Hort. 1037:269-276.

Wollaeger, H.M. and E.S. Runkle. 2015. Growth and acclimation of impatiens, salvia, petunia, and tomato seedlings to blue and red light. HortScience 50:522-529.

Zhang, T. and K. Folta. 2012. Green light signaling and adaptive response. Plant Signal. Behav. $7: 1-4$.

Zhen, S. and M.W. van Iersel. 2017. Far-red light is needed for efficient photochemistry and photosynthesis. J. Plant Physiol. 209:115-122. 